\title{
While Urine and Plasma Decorin Remain Unchanged in Prostate Cancer, Prostatic Tissue Decorin Has a Prognostic Value
}

\author{
Razie Rezaie ${ }^{1,2}$, Zeinab Falakian ${ }^{1,2}$, Saeideh Mazloomzadeh ${ }^{3}$, Mohsen Ayati ${ }^{4}$, \\ Arman Morakabati ${ }^{5}$, Mohammad Reza Teimouri Dastjerdan ${ }^{6}$, Mohammad \\ Zare $^{7}$, Minoosh Moghimi ${ }^{8}$, Tina Shahani ${ }^{1,2^{*}}$ and Alireza Biglari ${ }^{1,2^{*}}$
}

\begin{abstract}
${ }^{1}$ Department of Genetics and Molecular Medicine, School of Medicine, Zanjan University of Medical Sciences (ZUMS), Zanjan 45139-56111, Iran; ${ }^{2}$ Cancer Gene Therapy Research Center, Zanjan University of Medical Sciences (ZUMS), Zanjan 45139-56111, Iran; ${ }^{3}$ Department of Epidemiology and Statistics, School of Medicine, Zanjan University of Medical Sciences (ZUMS), Zanjan 45139-56111, Iran; ${ }^{4}$ Uro-Oncology Research Center, Tehran University of Medical Sciences (TUMS), Tehran 1419733141, Iran; ${ }^{5}$ Molecular Pathology Department of Mehr General Hospital, Tehran 1415755411, Iran; ${ }^{6}$ Urology Department of Farabi General Hospital, Mashhad 9178686918, Iran; ${ }^{7}$ Molecular Pathology Department of 17-Shahrivar General Hospital, Mashhad 91746, Iran; ${ }^{8}$ Department of Hemathology Onchology, Zanjan University of Medical Sciences (ZUMS), Zanjan 45139-56111, Iran
\end{abstract}

Received 7 January 2019; accepted 8 February 2019; published online 19 April 2020

\begin{abstract}
Background: Numerous studies confirmed that significant decrease in tissue DCN expression is associated to tumor progression and metastasis in certain types of cancer including PC. However, the potential prognostic value of tissue DCN in PC has not yet been investigated. Methods: A total number of 40 PC and 42 patients with BPH were investigated for the expression levels of DCN in their prostatic tissues using real-time qPCR and immunohistochemical analyses. Urinary and plasma DCN levels were also measured by ELISA. Results: Despite no significant changes in the mean of urine and plasma DCN concentrations between the two study groups, tissue DCN mRNA was found to be 5.5fold lower in cancer than BPH $(p=0.0001)$. Similarly, the stained DCN levels appeared significantly lower in cancer patients with higher Gleason Scores ( 8 and $9, n=6)$ than those with lower Gleason Scores ( 6 and $7, \mathrm{n}=26$ ), with a $p$ value of 0.049 . Conclusion: Here, we report, for the first time, that urine and plasma DCN does not seem to have a diagnostic value in PC, while tissue DCN could potentially be used as a prognostic marker in PC. DOI: 10.29252/ibj.24.4.229
\end{abstract}

Keywords: Benign prostatic hyperplasia, ELISA, Immunohistochemistry, Proteoglycans, Real-time qPCR

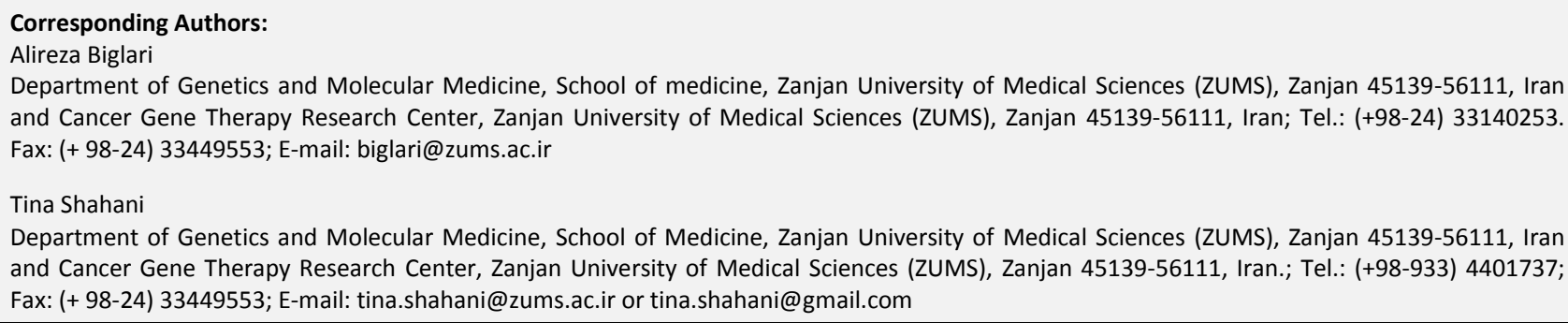




\section{INTRODUCTION}

$\mathrm{D}$ gital rectal exam, identification of prostatespecific antigen isoforms and tissue biopsy analysis are the current standard diagnostic approaches for PC. Yet, the later is the gold standard approach. In addition to serious adverse effects, which are common consequences of invasive diagnostic approaches, the above-mentioned protocols might lead to overtreatment ${ }^{[1]}$. Therefore, identifying specific fluid-based biomarkers that correlate the disease stage with histopathological features of the prostate are desirable. In this regard, extracellular matrix proteins such as DCN have catched the attention because of their key role in tumor progression and metastasis ${ }^{[2]}$.

DCN is a pan tyrosine kinase receptor inhibitor ${ }^{[3-6]}$ that prevents angiogenesis ${ }^{[7-9]}$ and induces autophagy ${ }^{[10]}$. Hence, it is referred as "Guardian of the matrix" "[1] . The role of tissue DCN as a prognostic marker in several types of cancer including breast, bladder, and lung carcinomas ${ }^{[12-14]}$ but not $\mathrm{PC}$ has been proposed. In PC, tissue DCN expression is shown to decrease compared with $\mathrm{BPH}^{[15]}$. Due to the proximity of prostate gland and urethra, we have hypothesized that DCN would leak into the urine and urinary DCN could potentially reflect the tumor progression. In addition to that, plasma DCN levels were studied. Potentially diagnostic low plasma DCN levels had previously been reported in esophageal cancer ${ }^{[16]}$ and urothelial carcinoma of bladder ${ }^{[13]}$, but not in breast carcinoma ${ }^{[17]}$. In this study, we aimed to compare plasma and urinary levels of DCN as well as tissue DCN mRNA and protein in PC versus BPH.

\section{MATERIALS AND METHODS}

\section{Study subjects and samples}

In total, 82 patients who had been admitted either to Mehr Hospital (Tehran, Iran) or Farabi Hospital (Mashhad, Iran) were recruited in this study. A total of 40 patients were diagnosed for PC and the rest for $\mathrm{BPH}$, based on histopathological analysis. Blood and urine collection from each patient was performed before any surgical intervention. Blood samples were collected in EDTA-containing tubes, centrifuged at $2000 \times \mathrm{g}$ for 15 minutes. The isolated plasma was then aliquated and kept frozen at $-80{ }^{\circ} \mathrm{C}$ until further processing. Urine samples were also collected in sterilized containers and preserved at $-80{ }^{\circ} \mathrm{C}$. Shipping duration was less than two hours, and all samples were carried on ice, then transferred to the Central Laboratory of the Department of Genetics and Molecular Medicine, Zanjan University of Medical Sciences, Zanjan, Iran. Tissue biopsies were obtained during radical prostatectomy, for cancer patients, or during transurethral resection of prostate, for patients with BPH. Tissue biopsies were collected in an RNApreservation buffer (RNAlater, Ambion, USA) and maintained at $4{ }^{\circ} \mathrm{C}$ up to 24 hours, before being transferred to $-80{ }^{\circ} \mathrm{C}$. Patients with metastasis, diabetes (fasting blood sugar $\geq 126 \mathrm{mg} / \mathrm{dl}$ ), renal failure (glomerular filtration rate $<60\left(\mathrm{~mL} / \mathrm{min} / 1.73 \mathrm{~m}^{2}\right)$, infectious, and inflammatory diseases or the history of stroke, transient ischemic attack history, and chemotherapy/radiotherapy were excluded from the study.

\section{ELISA for DCN}

Sandwich enzyme-linked immunosorbent assay (ELISA) was applied using DuoSet kit (DY143 R\&D systems, USA) according to the manufacturer's instruction, as described previously ${ }^{[17]}$. When measuring DCN in urine samples was desired, $2 \mathrm{ml}$ of urine was concentrated with the use of 30K-Ultra- 0.5 Centrifugal Filter tubes (Amicon, USA) first, and then assayed as explained, diluted or not. Urine samples were first morning voiding and patients did not have DRE; samples with pyuria were excluded.

\section{RNA extraction and real-time qPCR}

Total RNA was extracted from tissue samples using TRIzol reagent (Life Technologies, USA) according to the manufacturer's instruction. Quantity and quality of the extracted RNA were assessed on a fiber optic spectrometer (NanoDrop 2000c; Thermo Fisher Scientific, USA). RNA samples with 260/280 ratio, ranging from 1.8 to 2.1 , were used for downstream applications. DNA contaminations were removed by DNase I (Thermo Fisher Scientific) treatment and cDNAs were synthesized using Oligo dT primers (PrimeScript ${ }^{\mathrm{TM}} \mathrm{RT}$ reagent kit, Takara Bio Inc., Japan). Gene expression levels were then quantified on a StepOnePlus ${ }^{\mathrm{TM}}$ Real-Time PCR system (Applied Biosystems, USA), with a SYBR green-based method using $20 \mathrm{ng}$ cDNA of each sample per reaction. DCN transcript levels were normalized against the geometric mean of $\mathrm{h} T B P^{[18,19]}$ and $\mathrm{h} H P R T-1^{[19]}$ reference gene transcripts. Table 1 represents primer sequences, their targeting position and expected amplicon sizes. Relative gene expression (fold increase) was calculated by comparison to a single calibrator for all the amplicons using 2- ${ }^{\Delta \Delta \mathrm{Ct}}$ method; amplification efficiency was taken into account. A pool of total RNAs extracted from five prostate tissue biopsies was prepared and used to synthesize calibrator cDNA. Signal intensity generated from that cDNA was taken as calibrator. 
Table 1. Primer sequences to amplify DCN and internal control genes

\begin{tabular}{|c|c|c|c|c|}
\hline Gene & $\begin{array}{l}\text { Accession no./ } \\
\text { gene ID }\end{array}$ & Sequence ( $5^{\prime}$ to $\left.3^{\prime}\right)$ & $\begin{array}{l}\text { Nucleotide } \\
\text { position }\end{array}$ & $\begin{array}{c}\text { Amplicon } \\
\text { size (bp) }\end{array}$ \\
\hline$D C N$ & NM_001920.4/1634 & $\begin{array}{l}\text { F: CGAGTGGTCCAGTGTTCTGA } \\
\text { R: GACAAGAATCAATGCGTGAAG }\end{array}$ & $\begin{array}{l}595-614 \\
727-747\end{array}$ & 152 \\
\hline $\mathrm{h} T B P$ & NM_003194/6908 & $\begin{array}{l}\text { F: GAATATAATCCCAAGCGGTTTG } \\
\text { R: ACTTCACATCACAGCTCCCC } \\
{[18]}\end{array}$ & $\begin{array}{c}803-824 \\
1028-1009\end{array}$ & 226 \\
\hline $\mathrm{h} H P R T-1$ & NM_000194/3251 & $\begin{array}{l}\text { F: CAGACTGAAGAGCTATTGTAATGACCA } \\
\text { R: TGGCTTATATCCAACACTTCGTG }\end{array}$ & $\begin{array}{l}385-411 \\
591-613\end{array}$ & 229 \\
\hline
\end{tabular}

\section{Immunohistochemistry}

Paraffin-embedded tissue samples were cut into 4$\mu \mathrm{m}$ sections, deparaffinized with xylene and rehydrated. Antigen retrieval was performed with a solution containing $10 \mathrm{mM}$ Tris Base and $1 \mathrm{mM}$ EDTA solution at $\mathrm{pH} 9.0$, for one minute in a microvawe oven adjusted to 900 watt. After treatment with hydrogen peroxide, the slides were washed and incubated with MAB143 anti-human DCN monoclonal antibody (R\&D system, USA) diluted 40 times in PBS, for one hour at room temperature. To detect the primary antibody a solution of peroxidase-conjugated goat antimouse antibody (K5007; Dako REAL ${ }^{\mathrm{TM}}$ EnVision ${ }^{\mathrm{TM}} / \mathrm{HRP}$, Rabbit/Mouse, USA) was used as described by manufacturer. Color development was carried out with the use of $0.02 \%$ DAB solution (3-3' diaminobenzidine tetrahydrochloride, Dako) for 5 minutes at room temperature. Tissue sections were then analyzed under LX400, Labomed Inc microscope and images were generated with Labomed iVu 5100 digital imaging camera (Labo America, Inc. USA). In order to semi-quantify DCN expression in tissue sections, five fields of vision were randomly selected and color intensity was scored as negative (0), weak positive $(1+)$, moderate positive $(2+)$, or strong positive (3+).

\section{Statistical analysis}

The Kolmogorov-Smirnov test was used to evaluate the distribution of variables. For categorical variables, chi-square test was applied. Values are expressed as mean \pm standard deviation (mean \pm SD) and percentage number, when appropriate. Normally and non-normally distributed variables were compared using independent $t$-test and Mann-Whitney test, respectively. The association between PC and tissue DCN was adjusted by age using logistic regression models. $p$ values $<0.05$ are considered as statistically significant. All analyses were performed on SPSS 16.0 (SPSS Inc., USA).

\section{Ethical statement}

The above-mentioned sampling protocols were approved by the Ethics Committee of Zanjan University of Medical Sciences, Zanjan, Iran (ethical code: ZUMS.REC.1392.120; 24 Nov. 2013). Written informed consents were provided by all the patients.

\section{RESULTS}

Forty patients affected with PC with a mean age of $63.82 \pm 6.58$ years and 42 patients diagnosed for BPH with the mean age of $67.75 \pm 10.38$ years were studied. Body mass index values of $26.27 \pm 3.22$ and $24.90 \pm$ 5.68 were recorded for the cancer and BPH patients, respectively. While the difference between the mean age in the two groups was significant $(p=0.04)$, no significant difference was observed in the body mass index between the two groups.

In order to compare DCN protein levels in plasma and urine samples between the two study groups, ELISA was performed. As shown in Figure 1, the mean concentration of plasma DCN in cancer patients $(4.01 \pm 0.88 \mathrm{ng} / \mathrm{ml}, \mathrm{n}=40)$ was not significantly different from that of BPH patients $(3.85 \pm 0.67 \mathrm{ng} / \mathrm{ml}$, $\mathrm{n}=42 ; p=0.65)$. Similarly, comparing urinary DCN between 29 prostatic cancer $(20.24 \pm 17.17 \mathrm{pg} / \mathrm{ml})$ and $19 \mathrm{BPH}$ patients $(33.84 \pm 35.97 \mathrm{pg} / \mathrm{ml})$ who had measurable DCN levels did not appear significantly different $(p=0.81)$. It should be mentioned that ELISA was performed on urine samples from all the patients recruited in the study except for the samples of two BPH patients who had pyuria. However, DCN levels were undetectable in a number of samples even after 4times sample concentration.

The lack of difference in urine and plasma DCN levels between prostatic cancer and BPH patients could be due to the insignificant difference in tissue levels of DCN. Therefore, protein and transcript levels of DCN were both measured in tissue samples collected from the studied patients. DCN transcripts were detected in 30 of cancer and 20 of BPH patients by real-time qPCR. The mean expression level of DCN in cancer patients $(1.84 \pm 1.45, \mathrm{n}=30)$, as shown in Figure $2 \mathrm{~A}$, was 3.6 fold lower than that in the patients with BPH $(6.79 \pm 4.89, \mathrm{n}=20)$, with a $p$ value of 0.001 . Ageadjusted odds ratio for the association between PC and 

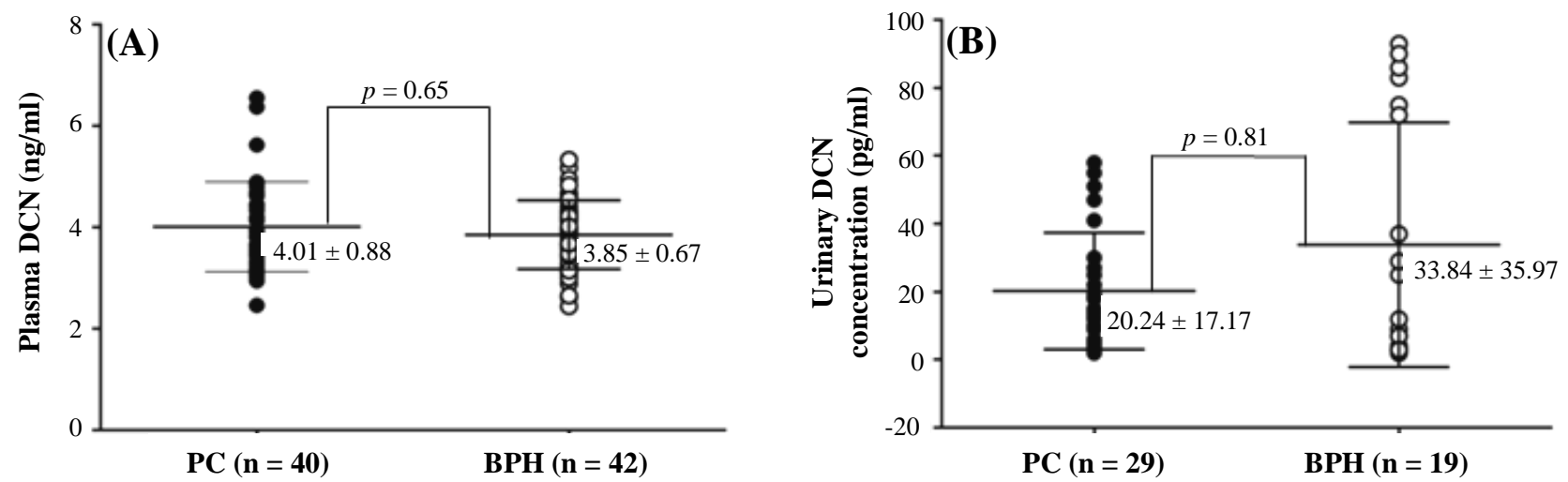

Fig. 1. Urine and plasma DCN levels in patients with PC compared with their levels in BPH patients. Distribution plot of the measured DCN levels in plasma (A) and urine (B) of prostatic cancer (filled circles) and BPH (empty circles) patients are depicted. Calculated mean \pm SD for each study group is also inserted. The difference in the mean \pm SD for the measured values between the two study groups was neither significant for plasma $(p=0.65)$ nor for urine DCN levels $(p=0.816)$. Assays are performed in triplicate for each sample. A single positive control was run in all assays for variation monitoring. No template controls were also included in each run.

tissue DCN expression was $1.05(95 \%$ CI, $1.01-$ 1.10). The observed difference was then compared with the outcome of immunohistochemistry for DCN proteins in the selected number of stained tissue sections (Fig. 2B). Mean of scores given to the intensity of stained DCN in PC tissue sections of 12 patients was 1.2 (ranged 1-3) compared with the mean of scores given to the stained biopsy sections of a similar number of BPH patients calculated as 2.41 (ranged 1-3).

Cancer patients were divided into two subgroups based on their Gleason Score (Table 2). DCN

(A)

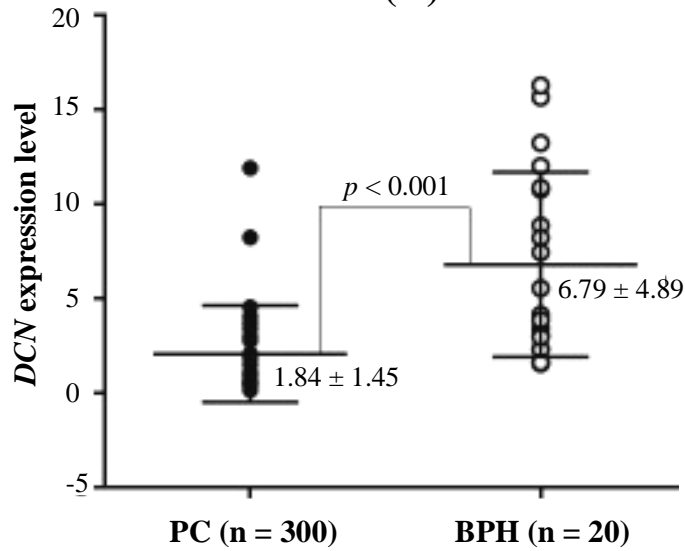

expression level in the samples with higher Gleason Scores ( 8 and $9 ; n=6$ ), estimated as $0.97 \pm 0.79$ and was found significantly lower than DCN expression level in the samples with lower Gleason Score (6 and $7 ; \mathrm{n}=26)$, estimated as $2.54 \pm 2.22(p=0.049)$. This observation provides supporting evidence for DCN expression level as a potential prognostic marker in $\mathrm{PC}$ tissue. However, the mean $\pm \mathrm{SD}$ of plasma DCN levels in the 6 patients with higher Gleason Score (8 and 9) measured as $4.17 \pm 0.97 \mathrm{ng} / \mathrm{ml}$ was not significantly different from those measured in the 26 patients with lower Gleason Score (6 and 7),
(B)

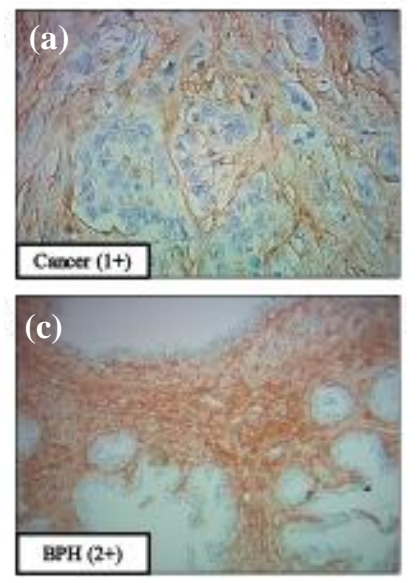

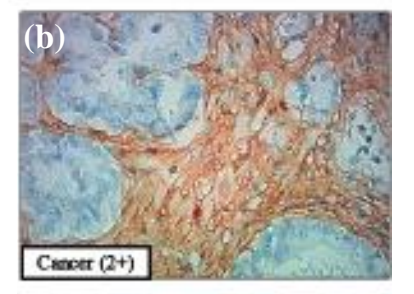

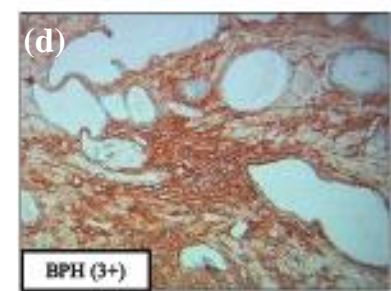

Fig. 2. DCN mRNA and protein expression in tumor biopsies from prostatic cancer versus BPH. (A) The tissue DCN transcript levels in prostatic cancer (filled circles) and BPH (empty circles), as measured by Real-time qPCR, are plotted. The difference in the mean expression level of DCN in cancer $(1.84 \pm 1.45, \mathrm{n}=30)$ versus BPH $(6.79 \pm 4.89, \mathrm{n}=20)$ was significant $(p=0.00)$. $(\mathbf{B})$ DCN is stained in prostatic tissue sections of cancer and/or BPH patients (a, b, c, d). a and b represent weak and moderate positive stromal expression of DCN in PC sections, respectively. Moderate and strong positive stromal expression of DCN observed in sections of prostatic BPH are presented in c and d, respectively. Neither weak staining $(+1)$ in BPH sections nor strong staining $(+3)$ in cancer sections were observed in this study. 
Table 2. Histological properties of tissue biopsies from prostatic cancer patients

\begin{tabular}{|c|c|c|}
\hline Variables & $\begin{array}{l}\text { Frequency } \\
(\mathbf{n}=\mathbf{3 2})\end{array}$ & Percentage \\
\hline \multicolumn{3}{|c|}{ Lymphovascular Involvement } \\
\hline Positive & 2 & 6.1 \\
\hline Negative & 31 & 93.9 \\
\hline \multicolumn{3}{|l|}{ Perineural Invasion } \\
\hline Positive & 27 & 81.8 \\
\hline Negative & 6 & 18.2 \\
\hline \multicolumn{3}{|c|}{ Seminal vesicle Involvement } \\
\hline Positive & 7 & 21.2 \\
\hline Negative & 26 & 78.8 \\
\hline \multicolumn{3}{|l|}{ Capsular Involvement } \\
\hline Positive & 8 & 24.2 \\
\hline Negative & 25 & 75.8 \\
\hline \multicolumn{3}{|l|}{ Metastatic lymph node } \\
\hline Positive & 3 & 9.1 \\
\hline Negative & 30 & 90.0 \\
\hline \multicolumn{3}{|c|}{ Prostatic intraepithelial neoplasia } \\
\hline Positive & 24 & 72.7 \\
\hline Negative & 6 & 18.2 \\
\hline Diffuse-high grade & 3 & 9.1 \\
\hline \multicolumn{3}{|l|}{ Gleason Score } \\
\hline 6 & 11 & 33.3 \\
\hline 7 & 15 & 46.8 \\
\hline 8 & 5 & 15.2 \\
\hline 9 & 1 & 3 \\
\hline
\end{tabular}

measured as $3.95 \pm 0.82(p=0.6)$. Similarly, no significant differences were observed for the urinary DCN levels in the 6 high Gleason Score patients $(22.67$ $\pm 15.66 \mathrm{pg} / \mathrm{ml}$ ) compared with the 19 patients low Gleason Score who had detectable amounts of DCN in their urine samples $(21.58 \pm 19.07 \mathrm{pg} / \mathrm{ml} ; p=0.7)$.

\section{DISCUSSION}

Measuring urine and plasma DCN levels in this study, we observed no significant difference between the patients with $\mathrm{PC}$ and $\mathrm{BPH}$, while significantly lower DCN expression was observed in prostatic cancer biopsies compared with BPH. Low DCN expression in cancerous tissue was expected as it has previously been reported not only in prostate ${ }^{[15,21,22]}$ but also in breast ${ }^{[23,24]}$ and bladder ${ }^{[25]}$ cancers. However, limited studies have reported an increased DCN expression in prostate ${ }^{[26]}$, as well as bladder ${ }^{[27]}$ and pancreas ${ }^{[28]}$ cancers.

Because of surrounding the urethra by prostate gland, we had hypothesized that DCN would leak into the urine. Although urinary DCN protein measured in samples of 29 cancer patients and 19 individuals with $\mathrm{BPH}$ were in a similar range, the impact of small sample size cannot be excluded. Larger sample size and sampling after $\mathrm{DRE}^{[29]}$ could provide a robust conclusion.

DCN could also be detected in the circulation. Plasma DCN levels have been shown to rise or decline in several pathological conditions such as diabetes, sepsis, and ischemic stroke ${ }^{[10]}$, as well as cancer ${ }^{[13,16,17]}$. Few studies have looked into the levels of DCN in the plasma of cancer patients. In the first study by $\mathrm{Wu}$ et $a l .{ }^{[16]}$, significantly lower DCN was measured in the plasma of 275 patients with esophageal cancer compared with 295 healthy individuals. Using a similar method, we measured 5.01 to $3.1 \mathrm{ng} / \mathrm{ml} \mathrm{DCN}$ in the plasma of all the studied patients, with no difference between PC and BPH. Similar to the study by Chen $\mathrm{Wu}$ et al. ${ }^{[16]}$, Appunni and colleagues ${ }^{[13]}$ have recently reported lower DCN expression in the serum of the patients with urothelial carcinoma of bladder than healthy individuals. In that study, $0.484 \mathrm{ng} / \mathrm{ml} \mathrm{DCN}$ was measured in the patients' blood serum compared with the controls $(0.804 \mathrm{ng} / \mathrm{ml})$. Despite the low DCN levels detected in that study, which could be explained by the removal of a major portion of circulating DCN along with the fibrinogen during serum preparation, the difference was significant ${ }^{[30,31]}$.

To our knowledge, this is the first study in which plasma DCN is measured in PC. Similar to the outcome of the present study, we have recently reported no significant difference in the plasma levels of DCN in patients with stages II and III of invasive ductal breast carcinoma compared with healthy individuals or patients having breast fibroadenoma ${ }^{[17]}$, the most frequent benign tumor of the breast.

Interesting with the current study is the lower DCN expression observed in cancerous tissues with higher Gleason Scores. Although those patients all had similar DCN levels in their urine and plasma, the prognostic value of tissue DCN in PC could be suggested from this study. The prognostic value of $\mathrm{DCN}$ in other types of cancer including node-negative invasive breast cancer, but not PC had been suggested previously ${ }^{[32,33]}$.

According to previous studies, insignificant $\mathrm{PC}$ is low-volume clinical T1c prostate carcinoma, and treatment for these patients may be unnecessary ${ }^{[34,35]}$. The potential prognostic value of $\mathrm{DCN}$, in combination with the current knowledge on the role of DCN in tumor progression, could also propose a role for $\mathrm{DCN}$ in differentiating significant tumors from insignificant ones.

In conclusion, immunohistochemical and qPCR analyses of DCN expression in the studied PC tissues have confirmed the decreasing trend of DCN 
expression with cancer progress. A similar phenomenon has been observed in bladder ${ }^{[25]}$ and breast cancers ${ }^{[23]}$. On the contrary, plasma and urinary DCN levels do not seem to have a diagnostic or prognostic value in PC. However, studying a larger patient population is strongly proposed before a robust conclusion could be made.

\section{ACKNOWLEDGMENTS}

We deeply thank all the patients who participated in this study. Our sincere gratitude also goes to Dr. Ghasem Rastegar-Lari and his colleagues at Iranian Comprehensive Hemophilia Care Centre in Tehran for providing us with their laboratory facilities at one stage of this study. This work is supported by Zanjan University of Medical Sciences (ZUMS) grant number A-12-65-2.

\section{CONFLICT OF INTEREST. None declared.}

\section{REFERENCES}

1. Hendriks RJ, van Oort IM, Schalken JA. Blood-based and urinary prostate cancer biomarkers: a review and comparison of novel biomarkers for detection and treatment decisions. Prostate cancer and prostatic diseases 2017; 20(1): 12-19.

2. Yu Q, Xin K, Miao Y, Li Z, Fu S, Hu S, Zhang Q, Zhou $S$. Anti-tumor responses to hypofractionated radiation in mice grafted with triple negative breast cancer is associated with decorin induction in peritumoral muscles. Acta biochimica et biophysica sinica 2018; 50(11): 1150-1157.

3. Edwards IJ. Proteoglycans in prostate cancer. Nature reviews urology 2012; 9(4): 196-206.

4. Sofeu Feugaing DD, Gotte M, Viola M. More than matrix: the multifaceted role of decorin in cancer. European journal of cell biology 2013; 92(1): 1-11.

5. Neill T, Painter H, Buraschi S, Owens RT, Lisanti MP, Schaefer L, Iozzo RV. Decorin antagonizes the angiogenic network: concurrent inhibition of Met, hypoxia inducible factor 1alpha, vascular endothelial growth factor A, and induction of thrombospondin-1 and TIMP3. The journal of biological chemistry 2012; 287(8): 5492-5506.

6. Buraschi S, Pal N, Tyler-Rubinstein N, Owens RT, Neill $\mathrm{T}$, Iozzo RV. Decorin antagonizes Met receptor activity and down-regulates \{beta\}-catenin and Myc levels. The journal of biological chemistry 2010; 285(53): 4207542085.

7. Iozzo RV, Buraschi S, Genua M, Xu SQ, Solomides CC, Peiper SC, Gomella LG, Owens RC, Morrione A. Decorin antagonizes IGF receptor I (IGF-IR) function by interfering with IGF-IR activity and attenuating downstream signaling. The journal of biological chemistry 2011; 286(40): 34712-34721.

8. Baghy K, Dezso K, Laszlo V, Fullar A, Peterfia B, Paku S, Nagy P, Schaff Z, Iozzo RV, Kovalszky I. Ablation of the decorin gene enhances experimental hepatic fibrosis and impairs hepatic healing in mice. Laboratory investigation 2011; 91(3): 439-451.

9. Vial C, Gutierrez J, Santander C, Cabrera D, Brandan E. Decorin interacts with connective tissue growth factor (CTGF)/CCN2 by LRR12 inhibiting its biological activity. The journal of biological chemistry 2011; 286(27): 24242-24252.

10. Buraschi S, Neill T, Goyal A, Poluzzi C, Smythies J, Owens RT, Schaefer L, Torres A, Iozzo RV. Decorin causes autophagy in endothelial cells via Peg3. Proceedings of the national academy of sciences of the United States of America 2013; 110(28): E2582-2591.

11. Neill T, Schaefer L, Iozzo RV. Decorin: a guardian from the matrix. American journal of pathology 2012; 181(2): 380-387.

12. Li SJ, Chen DL, Zhang WB, Shen C, Che GW. Prognostic value of stromal decorin expression in patients with breast cancer: a meta-analysis. Journal of thoracic disease 2015; 7(11): 1939-1950.

13. Appunni S, Anand V, Khandelwal M, Seth A, Mathur S, Sharma A. Altered expression of small leucine-rich proteoglycans (Decorin, Biglycan and Lumican): Plausible diagnostic marker in urothelial carcinoma of bladder. Tumour biology 2017; 39(5): 1010428317699112.

14. Hong X, Yang Z, Wang M, Wang L, Xu Q. Reduced decorin expression in the tumor stroma correlates with tumor proliferation and predicts poor prognosis in patients with I-IIIA non-small cell lung cancer. Tumour biology 2016; Epub ahead of print] reterieved from: https://www.ncbi.nlm.nih.gov/pubmed/27726099.

15. Suhovskih AV, Mostovich LA, Kunin IS, Boboev MM, Nepomnyashchikh GI, Aidagulova SV, Grigorieva EV. Proteoglycan expression in normal human prostate tissue and prostate cancer. ISRN oncologyl 2013: 680136.

16. Wu IC, Wu DC, Huang CC, Lin HS, Chen YK, Tsai HJ, Lu CY, Chou SH, Chou YP, Li LH, Tai SY, Wu MT. Plasma decorin predicts the presence of esophageal squamous cell carcinoma. International journal of cancer 2010; 127(9): 2138-2146.

17. Falakian Z, Shahani T, Rezaei R, Mazloomzadeh S, Sirati F, Jalilvand A, Bahmani P, Biglari A,Jadali F,Atarian S, Eghdam-Zamir R. Patients with Invasive ductal Carcinoma have reduced levels of decorin expression in their breast tissue of compared of patients with fibroadenoma while their plasma decorin remains unchanged. Archive of iranian medicine 2018; 21(11): 509-517.

18. Schmidt U, Fuessel S, Koch R, Baretton GB, Lohse A, Tomasetti S, Unversucht S, Froehner M, Wirth MP, Meye A. Quantitative multi-gene expression profiling of primary prostate cancer. The prostate 2006; 66(14): 1521-1534.

19. Tsaur I, Renninger M, Hennenlotter J, Oppermann E, 
Munz M, Kuehs U, Stenzl A, Schilling D. Reliable housekeeping gene combination for quantitative PCR of lymph nodes in patients with prostate cancer. Anticancer research 2013; 33(12):5243-5248.

20. Banerjee AG, Bhattacharyya I, Lydiatt WM, Vishwanatha JK. Aberrant expression and localization of decorin in human oral dysplasia and squamous cell carcinoma. Cancer research 2003; 63(22): 7769-7776.

21. Henke A, Grace OC, Ashley GR, Stewart GD, Riddick AC, Yeun H, O'Donnell M, Anderson RA, Thomson AA. Stromal expression of decorin, Semaphorin6D, SPARC, Sprouty1 and Tsukushi in developing prostate and decreased levels of decorin in prostate cancer. PLoS one 2012; 7(8): e42516.

22. Coulson-Thomas VJ, Gesteira TF, Coulson-Thomas YM, Vicente CM, Tersariol IL, Nader HB, Toma L. Fibroblast and prostate tumor cell cross-talk: fibroblast differentiation, TGF-beta, and extracellular matrix down-regulation. Experimental cell research 2010; 316(19): 3207-3226.

23. Oda G, Sato T, Ishikawa T, Kawachi H, Nakagawa T, Kuwayama $T$, Ishiguro $M$, Iida $S$, Uetake $H$, Sugihara K. Significance of stromal decorin expression during the progression of breast cancer. Oncology reports 2012; 28(6): 2003-2008.

24. Leygue E, Snell L, Dotzlaw H, Troup S, HillerHitchcock T, Murphy LC, Roughley PJ, Watson PH. Lumican and decorin are differentially expressed in human breast carcinoma. The journal of pathology 2000; 192(3): 313-320.

25. Sainio A, Nyman M, Lund R, Vuorikoski S, Bostrom P, Laato M, Bostrom PJ, Jarvelainen H. Lack of decorin expression by human bladder cancer cells offers new tools in the therapy of urothelial malignancies. PLoS one 2013; 8(10): e76190.

26. Ricciardelli C, Mayne K, Sykes PJ, Raymond WA, McCaul K, Marshall VR, Horsfall DJ. Elevated levels of versican but not decorin predict disease progression in early-stage prostate cancer. Clinical cancer research 1998; 4(4): 963-971.

27. El Behi M, Krumeich S, Lodillinsky C, Kamoun A, Tibaldi L, Sugano G, De Reynies A, Chapeaublanc E, Laplanche A, Lebret T, Allory Y, Radvanyi F, Lantz O, Eijan AM, Bernard-Pierrot I, Thery C. An essential role for decorin in bladder cancer invasiveness. $E M B O$ molecular medicine 2013; 5(12): 1835-1851

28. Koninger J, Giese NA, di Mola FF, Berberat P, Giese T, Esposito I, Bachem MG, Buchler MW, Friess $\mathrm{H}$. Overexpressed decorin in pancreatic cancer: potential tumor growth inhibition and attenuation of chemotherapeutic action. Clinical cancer research 2004; 10(14): 4776-4783.

29. Hendriks RJ, Dijkstra S, Jannink SA, Steffens MG, van Oort IM, Mulders PF, Schalken JA. Comparative analysis of prostate cancer specific biomarkers PCA3 and ERG in whole urine, urinary sediments and exosomes. Clinical chemistry and laboratory medicine 2016; 54(3): 483-492.

30. Dugan TA, Yang VW, McQuillan DJ, Hook M. Decorin modulates fibrin assembly and structure. The journal of biological chemistry 2006; 281(50): 38208-38216.

31. Dugan TA, Yang VW, McQuillan DJ, Hook M. Decorin binds fibrinogen in a $\mathrm{Zn} 2+-$ dependent interaction. The journal of biological chemistry 2003; 278(16): 1365513662.

32. Troup S, Njue C, Kliewer EV, Parisien M, Roskelley C, Chakravarti S, Roughley PJ, Murphy LC, Watson PH. Reduced expression of the small leucine-rich proteoglycans, lumican, and decorin is associated with poor outcome in node-negative invasive breast cancer. Clinical cancer research 2003; 9(1): 207-214.

33. Cawthorn TR, Moreno JC, Dharsee M, Tran-Thanh D, Ackloo S, Zhu PH, Sardana G, Chen J, Kupchak P, Jacks LM, Miller NA, Youngson BJ, Iakovlev V, Guidos CJ, Vallis KA, Evans KR, McCready D, Leong WL, Done SJ. Proteomic analyses reveal high expression of decorin and endoplasmin (HSP90B1) are associated with breast cancer metastasis and decreased survival. PLoS One 2012; 7(2): e30992.

34. Bastian PJ, Carter BH, Bjartell A, Seitz M, Stanislaus P, Montorsi F, Stief CG, Schröder F. Insignificant prostate cancer and active surveillance: From definition to clinical implications. European urology 2009; 55(6): 1321-1331.

35. Bastian PJ, Mangold LA, Epstein JI, Partin AW. Characteristics of insignificant clinical T1c prostate tumors. Acontemporary analysis 2004; 101(9): 20012005. 